Кандидати техн. наук О.І. Акімов, Ю.О. Акімова

\title{
ПІДВИЩЕННЯ ЕФЕКТИВНОСТІ ПРОФІЛАКТИЧНИХ ВИПРОБУВАНЬ КАБЕЛЬНИХ ЛІНІЙ ЕЛЕКТРОПЕРЕДАЧІ
}

\author{
Представив д-р техн. наук, професор Ю.І. Гусевський
}

\begin{abstract}
Постановка
проблеми. Досвід кабельних ліній

експлуатації електропередачі (КЛЕП), що входять до
складу систем електропостачання електрифікованих залізниць, показує, що навіть при проведенні профілактичних випробувань таких кабелів підвищеною постійною напругою частка їх відмов, що відбуваються під час експлуатації, залишається високою. Це свідчить про низьку ефективність профілактичних випробувань, що проводяться за діючими у теперішній час регламентованими нормами i технологіями [1]. Такі випробування не в змозі виявити всі дефекти ізоляції КЛЕП, час розвитку яких до пробою ізоляції знаходиться в межах одного міжпрофілактичного періоду. Таким чином, постає питання про підвищення ефективності профілактичних випробувань КЛЕП.
\end{abstract}

Аналіз останніх досліджень i публікацій. Дослідженню й аналізу ситуації, що пов'язана 3 профілактичними випробуваннями кабельних ліній, присвячені праці багатьох вчених [2-8]. Основний напрямок їх робіт - це вирішення таких проблем: величини напруги, при якій треба вимірювати часткові розряди [4]; відмова від випробувань підвищеною напругою кабельних ліній через руйнування ізоляції в проблемних місцях частковими розрядами [5]; відмова від випробувань підвищеною напругою взагалі, оскільки при цьому не визначається залишковий ресурс кабелю $[6,7]$; величини випробної напруги, іiі форми, а також можливість зниження випробної частоти.
Зміна часу прикладання випробної напруги залишилася за межами розгляду.

Мета статті. Метою статті $\epsilon$ обгрунтування способів підвищення ефективності профілактичних випробувань КЛЕП i, зокрема, підвищення часу прикладення випробної напруги.

Основна частина. Підвищення ефективності профілактичних випробувань КЛЕП може бути досягнуто щонайменше двома шляхами:

- удосконаленням методики проведення випробувань таким чином, щоб отримати можливість виявляти дефекти на більш ранній стадії їх розвитку і тим самим добитися скорочення кількості пробоїв ізоляції КЛЕП в міжпрофілактичній період;

- проведенням контролю, що доповнює випробування КЛЕП За існуючою методикою i несе інформацію про дефекти, які є та розвиваються, і які не були виявлені при випробуваннях, але пробій ізоляції через їх наявність можливий в міжпрофілактичній період 3 достатньо високою ймовірністю.

Одним 3 найчастіших шляхів удосконалення методики проведення випробувань, що обговорюються, $\epsilon$ збільшення часу прикладення випробної напруги.

При профілактичних випробуваннях кабельної ізоляції частина дефектів, миттєва електрична міцність яких нижче випробної напруги, буде виявлена під час підняття цієї напруги. Одночасно прискорюється процес втрати міцності дефектів, розвиток яких залежить від часу прикладення випробної напруги. Якщо під 
час випробувань їх електрична міцність знизиться до випробної напруги, то вони також будуть виявлені.

Енергія руйнування дефекту (W) при випробуваннях постійним струмом [2, 3] пропорційна часу прикладення випробної напруги:

$$
W=E^{2} \gamma,
$$

де $E$ - напруженість поля, А/м;

$\gamma$ - питома об'ємна провідність ізоляції;

$t$ - час прикладення випробної напруги.

Напруженість поля залежить від величини випробної напруги та товщини ізоляції. Провідність визначається товщиною, станом ізоляції та випробною напругою, із збільшенням якої провідність збільшується. Товща і стан ізоляції в місці дефекту випадкові, тому і час, необхідний для виявлення дефекту, також випадковий $\mathrm{i}$ може бути визначений статистично.

Дослідні дані, отримані під час профілактичних випробувань КЛЕП [7], дозволили визначити функцію розподілу часу до пробою дефектів при дії випробної напруги постійного струму, яка відповідає показовому розподілу (рис. 1) із середнім часом до пробою ізоляції в місцях дефектів, рівним 1,1 хв:

$$
P(t)=e^{-\frac{t}{T_{\mathrm{Cpp}}}}=e^{-0,91 t},
$$

де $P(t)$ - функція розподілу часу до пробою ізоляції в місці дефекту при випробуванні напругою постійного струму;

$T_{\text {сер }}$ - середній час до пробою ізоляції.

Крива, зображена на рисунку, дозволяє визначити тривалість прикладення випробної напруги, що забезпечує із заданою ймовірністю виявлення дефектів. Близько $95 \% 3$ них може бути виявлено при випробуванні кабелів протягом 3-4 хв.

Статистичний аналіз результатів випробувань КЛЕП показав, що тривалість випробувань до 10 хв забезпечує високу ефективність випробувань і більші тривалості малокорисні [3].

Недоцільність збільшення тривалості випробувань витікає 3 самого методу випробувань підвищеною напругою постійного струму через виявлення ним сильнорозвинутих дефектів i практичну відсутність іонізаційного старіння [5].

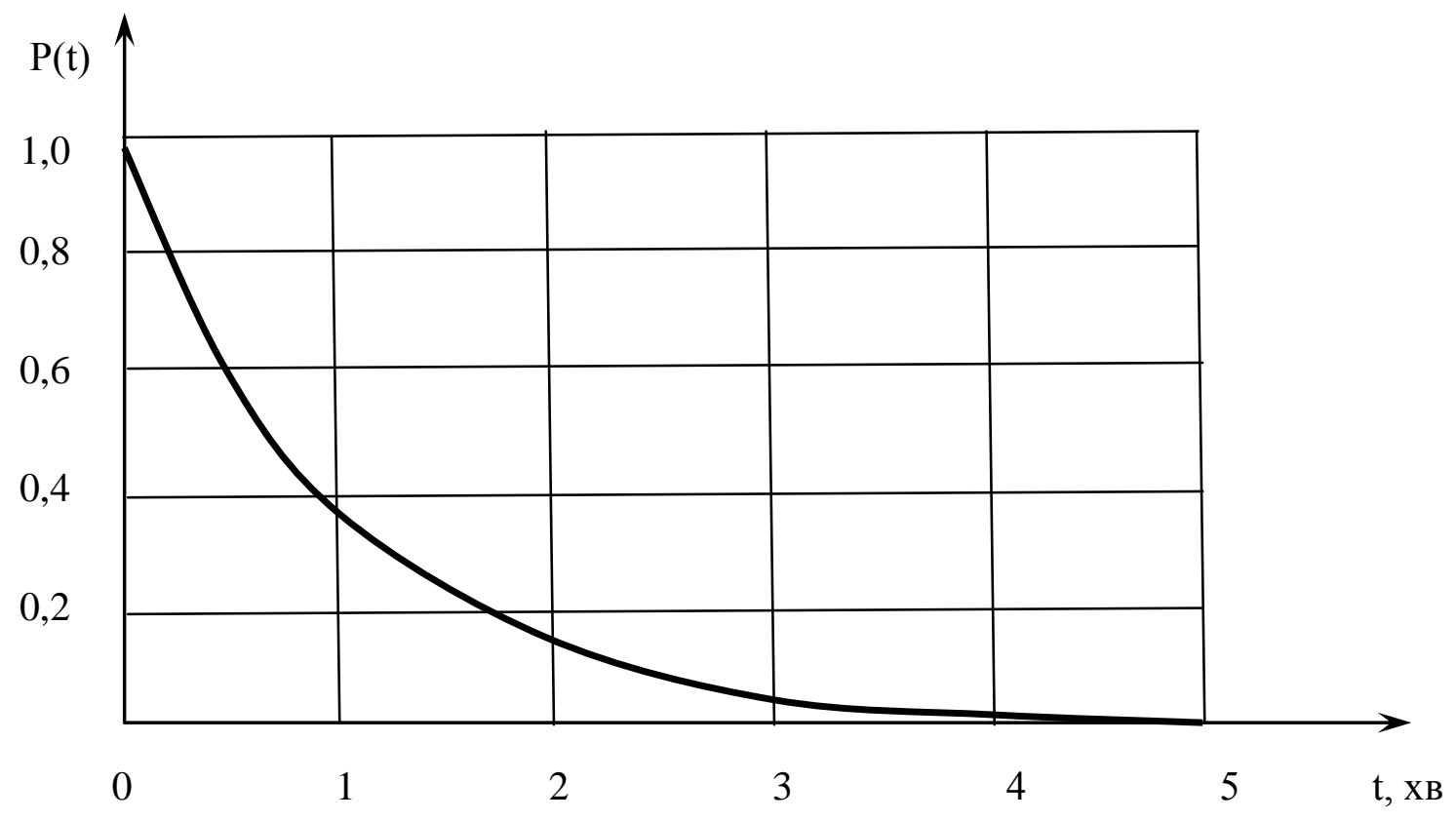

Рис. Визначення часу прикладення підвищеної напруги постійного струму при випробуваннях КЛЕП 
Аналіз часу прикладення випробної напруги i напруги початку іонізації показав, що до $90 \%$ розвинутих дефектів будуть виявлені протягом 5 хв [2].

\section{Висновки}

1. Прийняті в теперішній час при випробуваннях КЛЕП підвищеною напругою постійного струму норми часу випробувань $є$ раціональними і збільшення часу випробувань КЛЕП недоцільно.

2. Доцільно розглянути способи контролю, який доповнює випробування КЛЕП та має інформацію про дефекти ізоляції, що розвиваються.

\section{Список літератури}

1. Правила технической эксплуатации электроустановок потребителей [Текст]: утверждено приказом Министерства топлива и энергетики № 258 от 25 июля 2006 г. (в редакции приказа Министерства энергетики и угольной промышленности №91 от 13 февраля 2012 г.). - Харьков: Изд-во «Форт», 2012. - 404 с.

2. Вайда, Д. Исследования повреждений изоляции [Текст] / Д. Вайда; пер. с венг. Т.З. Партоша; под ред. Д.В. Разевига. - М.: Энергия, 1968. - 400 с.

3. Городецкий, С.С. Испытания кабелей и проводов [Текст]: учеб. пособие для техникумов / С.С. Городецкий, Р.М. Лакерник. - М.: Энергия, 1971. - 272 с.

4. Ковригин, Л.А. Выбор испытательного напряжения при измерении частичных разрядов в кабелях на среднее напряжение [Текст] / Л.А. Ковригин, Л.Г. Сидельников // Кабель-news: информационно-аналитический журнал. - 2009. - № 11. - C. 56-58.

5. Войлошников, В. Технические требования по испытаниям кабельных линий в сетях 0,4-10 кВ [Текст] / В. Войлошников // Кабель-news: информационно-аналитический журнал. - 2008. - № 10. - С. 61-63.

6. Копченков, Д.М. Современные методы и оборудование для испытаний, определения мест повреждений и диагностики силовых кабелей [Текст] / Д.М. Копченков, В.Н. Кольцов // Кабель-news: информационно-аналитический журнал. - 2009/2010. - № 12-1. - С. 67-69.

7. Канискин, В.А. Оценка технического состояния кабелей и кабельных сетей [Текст]: монография / В.А. Канискин, А.А. Пугачев, А.И. Таджибаев. - С.Пб.: ПЭИПК, 2007. - 173 с.

8. Борисов, А.М. В России должны быть единые нормы для испытания кабелей [Текст] / А.М. Борисов // Кабель-news: информационно-аналитический журнал. - 2010. - № 3. C. $49-50$.

Ключові слова: підвищення, ефективність, профілактичні випробування, кабельні лінії, дефекти ізоляції, пробій, збільшення часу

\section{Анотації}

Розглядаються можливості підвищення ефективності профілактичних випробувань кабельних ліній електропередачі за рахунок збільшення часу прикладення випробної напруги.

Рассматриваются возможности повышения эффективности профилактических испытаний кабельных линий электропередачи за счет увеличения времени приложения испытательного напряжения.

In the article increase of efficiency of preventive testing of electricity transmission cable lines by increase of application time of testing voltage are considered. 